\title{
The book at the outskirts of culture: Cortázar's first almanac
}

\author{
José Sanjinés \\ Coastal Carolina University, \\ P.O. Box 261954, Conway, SC 29528-6054, U.S.A. \\ e-mail: sanjines@coastal.edu
}

\begin{abstract}
The notion of intersemiosis suggests the game relationships between the multiple interacting signifying spheres of culture, but the term can also be fitly applied to the study of certain extraordinary artistic texts. This study makes use of one such book, Julio Cortázar's Around the Day in Eighty Worlds, to show how the sui generis interplay of the book's semantic spheres simultaneously models and renews the complex cultural processes of the production of meaning. This often reprinted and hard-tocategorize book that for years has remained at the outskirts of Latin American culture is also an ideal example to explore the dynamics between the center and periphery of culture as well as the writer's role in the creative renewal of cultural repertoires. By drawing a bridge over the apparent gap between the semiotics of culture and the semiotics of the artistic text, the present study attempts to approximate the critical-creative spirit of the late great theoretician Yurij Lotman.
\end{abstract}

to Glenda

The term intersemiosis evokes a zone of encounter and play between diverse semiotic systems, and it also elicits the frontiers between these systems. At first, the term brings to mind the semiotic structure of culture because culture is composed of a multiplicity of heterogeneous systems that are at constant interplay. Moreover, a culture is never found by itself; a culture is defined by contrast to other cultures (thus the common distinction of we vs. they), and a culture is renewed by its interaction with other cultures (some of the most exciting "hot spots" 
of semiotic dynamism are the result of the clash and mix of two or more opposing cultural repertoires ${ }^{1}$ ). Intersemiosis also brings to mind art forms composed of more than one semiotic language such as cinema, audio-visual performances, or bj,ooks containing both verbal and visual signs. ${ }^{2}$

Upon further consideration, however, one can see that the concept of intersemiosis can also be fitly applied to the description of any complex system in which semantic units enter into a play of contrasts and correspondences. The iconic principle of verbal art, natural language's capacity to generate images in the reader's mind, for instance, makes of literature a space of intersemiosis in which the narrative and iconic aspects of language are in constant interaction and tension. These two aspects, the capacity to tell and to show, are perhaps the most obvious, but by no means the only, forms of intersemiosis in the literary text. Let us take one more example. The old practice of rhetoric, as the late French theorist Roland Barthes pointed out in $L$ 'ancienne rhétorique, conceived language as being composed of two distinct states of semiosis: "there is a naked, pure level of communication, a base from which one can construct a more complicated expression, adorned, gifted with a larger or smaller distance with respect to the original base" (Barthes 1974: 72-73). The interaction in a given text between these two elementary rhetorical states can also be understood as a form of intersemiosis.

It should be noted here that the amount of information generated by the process of intersemiosis - what we may call the semiotic richness of a complex system - may depend more on the semantic distance between different forms of semiosis in a single medium than on the congruence of signs produced in different media: a traditional illustrated book in which the visual art strives to correctly translate the verbal images, or a situation comedy in which canned laughter interprets for the viewer the humor of a scene, for instance, can say less than the unexpected juxtaposition of seemingly incompatible verbal images in a poetic text. ${ }^{3}$ The coexistence and tension between distant

I use the term repertoire here in the sense given to it by Israeli semiotician Itamar Even-Zohar (1999: 7), that is, the invented set of cultural options by means of which we conduct our lives.

2 The notion of illustrated book, as I have argued before (1993), inadequately describes the complex semiotic interactions between verbal and visual signs in the art form of the book.

3 The principle of the production of meaning by means of the encounter of distant semantic realms is not only central to the poetics of western artistic manifestations 
semiotic systems is also one of the defining characteristics of culture. I am referring here to culture as seen from a critical, external perspective, that is, from a metasystemic point of view, and not to the usual conception of culture as seen from the inside which validates and accepts some cultural manifestations and excludes others.

As Yuri Lotman described in The Universe of the Mind (1990), customary semiotic systems at the core of a given culture are in constant dialectical tension with divergent and unconventional systems at the periphery. Lotman was drawing from the relatively young tradition of cultural semiotics. The idea that, seen from the outside, "the mechanism of culture is a system which transforms the outer sphere into the inner one: disorganization into organization, ignoramuses into initiates, sinners into holy men, entropy into information" (Uspenski 1998: 34), was first proposed in 1973 by B. A. Uspenski, V. V. Ivanov, V. N. Toporov, A. M. Pjatigorski, and Lotman himself in the seminal "Theses on the Semiotic Study of Cultures." The "game relationship" (36) between the outer and inner spheres of culture that these authors identified must be understood in the context of the complex interplay of semiosis between the myriad of competing codes and structural levels in a given culture.

It is in this context that I would like to discuss here an extraordinary book that seems to me not only to model the processes of cultural intersemiosis, but that also seeks to redefine and renew them, a book informed by the "classics"4 yet unusually receptive to the undervalued worlds of semiosis at the edge of culture, a revolutionary text open to anything that might happily deautomatize our expectations of art, culture, and life. I am referring to La vuelta al día en ochenta mundos (Around the Day in Eighty Worlds) written by the late FrancoArgentine writer Julio Cortázar (1914-1984). This is a book that offers us a new repertoire of ways to see the world, a deck of surprises, an unaccustomed interplay of signifying systems at play in a zone between the accepted and peripheral spheres of culture.

such as romanticism and surrealism but also to that of many oriental and preColumbian cultures.

4 Roland Barthes (1974: 24) reminds us that "the expression 'classic' ('classicism') originated in the opposition proposed by Aulo Gelio (second century) between the classicus and the proletarius author: an allusion to Servio Tulio's constitution which divided citizens according to their fortune in five classes, the first of which was the classici (the proletarii were outside the classes); classical, therefore, etymologically means one who belongs to the cream of society (richness and power)." (My translation.) 
When it was first published simultaneously in Mexico and Buenos Aires in 1967 by Siglo XXI Editores, Around the Day had an immediate impact on Latin American readers. Since then it has been reprinted close to thirty times; yet, it has never stopped being an exemplary peripheral book, and this is true both in the context of Latin American culture as it is in the context of Cortázar's corpus. Around the Day seems to belong today at once both to the "canon" and to the "avantgarde" of Latin American literature, it is one of those well-read books that has paradoxically received little critical recognition. Elusive to classification, the book is often described by critics in brief, cursory terms, as if it were too difficult to situate critically. This, of course, does not imply that a text can place itself outside a metasystemic cultural perspective: any text that participates in the flux and reflux of culture must be a part of it. The work of a "minor poet" or an "avantgarde artist" that may be marginal today and key tomorrow is by no means less an integral part of culture than the work of a so-called "classic" author that has managed to retain its semiotic vitality beyond the passage of time.

It has been over thirty years since the first edition of Around the Day in Eighty Worlds, and the book remains daring and modern. It is an extrageneric text, neither a collection of essays nor a novel, at times poetic and fictional and at others factual and journalistic, falling somewhere between the metasystemic description of cultural manifestations and the creative impulses of imagination that have the power not only to expand a cultural tradition, but also to transform and renew it. The enchanting first edition, as well as the many that would follow, is composed of both verbal and visual art and was designed in collaboration with Argentine artist Julio Silva. The numerous pocketbook editions that date to 1970 transposed most of the verbal and visual art into two slim volumes of less than 200 pages each that are meant to fit in a small pocket and travel well. I say that most of the art was transposed because Cortázar feels free to change the order of the texts, to elide and replace some of the visual art and, notably, to hold back on a series of four personal poems dating back to 1950 ("Razones de la cólera") which, as he confesses in the first edition, he had not published until then due in part, and I translate, to a "perverse pleasure of keeping mine what is most mine" (Cortázar 1967: 195). In doing so, Cortázar is consequent to his desire to write "nothing but takes" (Cortázar 1967: 172), in the sense given to this term in jazz to the successive recordings of the same theme. 
Around the Day in Eighty Worlds is first and foremost a text intended to motivate writing and incite creativity; like a succession of jazz takes, each piece of the book calls for other takes and recreations. Consequently, the book has had its share of epigones, quite a few of them no doubt prompted by its playful and translatable title, a transposition of Jules Verne's imaginary voyage around the globe in, as I remember it from childhood readings, a rather flimsy balloon. The ingenious transposition of Around the World in Eighty Days to Around the Day in Eight Worlds signals play, and it also marks a passage from diachrony to synchrony, from a journey in which a series of concatenated adventurous events take place in a relatively lengthy period of time, to one in which a different series of no less adventurous imaginary worlds coexist simultaneously in a rather short span of time: in a single day, in the orb of a book. As the visual art in the black and white cover of both thin volumes of the portable editions prefigure, countless semantic worlds of imagination are indeed at play in Around the Day. ${ }^{5}$ In the now well-known illustration by Grandville, a mustachioed man playfully juggles countless worlds to the bewilderment of a little nineteenth century spectator who can see that one of the worlds has fallen in the juggler's pants and that another has turned into a Croix d'honneur which is about to crash over his head. ${ }^{6}$

The high degree of narrative content in the book's cover is significant - throughout the book Cortázar uses images not only that show but also that tell. Cortázar liked to swim against the current, and so he made his way Around the Day telling with images and showing with words, that is to say, going against the primary semiotic properties of verbal and visual signs. In Around the Day verbal and visual art strive to show and tell in unison; ${ }^{7}$ the content of both of verbal and visual modalities is polymorphous and eludes conventional expectations, and so does the book's organizing principle. Around the Day is at once both an aesthetically integrated and decentered constellation of semi-

\footnotetext{
In an article on the visual world of Around the Day ("El mundo visual en La vuelta al dia en ochenta mundos"), Andrea Varricchio discusses the different drawing that features on the cover of one of the first hard cover editions of the book.

6 The illustration is by Jean Ignace Gérard, a.k.a. Grandville (1803-1847).

7 This is a semiotic gesture that Cortázar and Silva would take one step further in the first edition Último round (1969). Behind its cover, the book is split into two independent sets of pages, a larger set above and a slimmer one below, so that the pages of each set can be turned separately from each other. Thus, the reader/viewer may read a text in the upper section while viewing the visual art in the lower one or vice versa; or the he/she may choose to counterpose the pages of two sets of verbal art with two sets of visual art, or the pages of two mixed sets of verbal and visual art against each other.
} 
otic systems, a space of intersemiosis open as much to references of what Cuban writer José Lezama Lima aptly called "the memorable, monumental culture" ${ }^{8}$ as it is to the discourses of the periphery.

Around the Day is indeed a hard-to-categorize book. In it we find in fraternal tension and coexistence references to jazz, Shakespeare, happenings, madness, esoteric knowledge, cats, Jack and other famous rippers, colloquialisms, a praise of idiocy, advertising, oriental mandalas, permutable poems and poems to be completed by the reader, tricks of memory, the melancholy of suitcases, boxing, hints to deautomatize daily experience, the horror of war, kitsch, surrealism, and always humor and many other unexpected interventions of the extraliterary and miraculously mundane. All this and much more in a rich semantic play with the distances and vicinities of a deck of visual reproductions that resemble more a tarot of the uncharted than an illustrated tour.

In his introduction to The Universe of the Mind, Umberto Eco wishes to "draw attention to a crucial definition" (xii) in which Lotman describes the semiosphere, i.e., the space of intersemiosis in which the many codes of a given culture come into play with each other:

[...] imagine a museum hall where exhibits from different periods are on display, along with inscriptions in known and unknown languages, and instructions for decoding them; then there are also the explanations composed by the museum staff, plans for tours and rules of behaviour of the visitors. Imagine also in this hall tour-leaders and visitors and imagine all this as a single mechanism (which in a certain sense it is). This is an image of the semiosphere. (xii)

The dynamic complexity of Lotman's notion of the semiosphere cannot of course be captured in a brief single quote. But the image of the semiosphere, and by extension of culture, as a museum is nonetheless significant.

I have suggested that Around the Day in Eighty Worlds is a book that models and recreates the processes of cultural intersemiosis. Indeed, many of Lotman's descriptions of the semiosphere can be aptly applied to the description of this book. Like culture, Around the Day in Eighty Worlds, is a complex message composed of an array of in-

\footnotetext{
8 "Cortázar and the Beginning of the Other Novel" (1972: 18). As Lezama Lima suggests in the same page of this essay, Cortázar is certainly one of the best read writers of the twentieth century: Cortázar, Lezama Lima writes, "ostentatiously displayed a fan of artistic and literary references of insuperable extension”. (My translations.)
} 
tercommunicating vessels, and like culture, too, these meaningful channels support one another and are unified in ways that uphold their independence as immanently organized systems. The initial premise of the "Thesis on the Semiotic Study of Cultures" states that "all human activity concerned with the processing, exchange, and storage of information possesses a certain unity" (Uspenski 1998: 33); this is true for a culture as a whole as much as for the individual signifying systems that comprise it.

Little if any, however, has been said about the features that distinguish the unifying principles of the work of art from those of culture. Most of the prevalent expressions of verbal art, such as the novel, the essay, the short story, and poetry, ${ }^{9}$ end up submitting to the impulse of logical or aesthetic coherence which at once distinguishes them from other works and secures them an inner place in the gallery of culture. In Around the Day, Cortázar abstains from this tendency; instead, he allows for a sort of sympathetic magic that coalesces various pieces of the book and resembles the secret affinities that bring together the disparate strands that intervene in a given culture.

But this is not the single unifying principle of the book. The highest form of a semiotic system is when it describes itself; this is as true in literature as it is in culture. In some of its first pieces Around the Day talks about itself, but it does so in such a way as to leave the door ajar for the free interplay of chance associations and unexpected encounters. It is clear that this is a text permeable to the partial and oft ignored languages at the periphery of culture, and it is clear too that it is aware of bringing them into its orb. A few pages into the book we are invited to the Cortazars' summer home in the southern French town of Saignon, where we meet for the first time their cat Teodoro W. Adorno; and in one of the last texts, at the end of Around the Day, Cortázar returns us to the place where the journey began: the summer has ended, the book is over, it rains; Teodoro senses the imminent departure of the couple, and the kitty is "full of whims and sprints in all directions" (Cortázar 1980: 167).

I suggested that Around the Day seeks to transform and renew the processes of cultural intersemiosis. This is a book that presents itself as a permeable territory open to the diverging sways of culture, a hot

\footnotetext{
9 Something similar can be said of most expressions of semiosis made up of nondiscrete, continuous sign systems such as painting, music, and sculpture, as well as of other complex forms of intersemiosis such as dance, theater, television productions, and film.
} 
zone for unexpected encounters, a model for creative acts capable of expanding the horizons of what we understand as culture. Keeping in mind and as a contrast the image of a museum, I would like to draw attention to the first piece of visual art in the book, a drawing which I will call here a permeable aquarium that may very well serve as an emblem for the whole book. In it, a set of fantastic critters either float or rest still in the confines of a transparent rectangular object which may be filled with air or water: among them are a horse, a cat, a bird, a wild boar, and a dog — and all of them are depicted with fish tails. These unpretentious mythical critters commingle with a little star, a clove playing card, a treasure chest, a capital letter D or A, depending on the angle of vision, a horseshoe, a lance, a wolf, a banana, a few scattered plants, and an air balloon reminiscent of the one in Verne's Around the World in Eighty Days. I have called this transparent rectangle a permeable aquarium because there are in it some partial figures - the head of a sheep, the tail of squirrel or a bunny - that seem to infuse the aquarium's margins. I also called it permeable because the book itself is organized around what we may call the poetics of the sponge, a semiotic territory where the real commingles with the imaginary, where jazzman Clifford Brown can freely swing in and out of the confines of classification with a caged pet mandrake. Cortázar invites us to presuppose that semiosis may by found where we least expect it: why should we reserve our enthusiasm for the night in which King Lear is shown when before us we see a dew laced spider web shining bright against the sun ${ }^{10}$

A museum, it seems to me, is the sanctioned zone where the repertoire of (most often visual) cultural productions is admitted into the mainstream of culture - the extreme example, of course, was set by Marcel Duchamp, who dared to sign his pseudonym on an urinal, which he titled Fountain, and send it to an exhibition. ${ }^{11}$ For Cortázar, who thought Duchamp's life was itself an act of imagination, the idea of culture includes not only past and present works that have become acceptable and remarkable, but also the many inadvertent surprises of

\footnotetext{
10 Cf. "Hay que ser realmente idiota para..." (Cortázar 1980: 161-167). In another ironic and confessional piece titled "The Pigeonhole of the Chameleon", Cortázar reminds us that "Nietzche, who was a cronopio as few others [I will return to this term later], said that only idiots don't contradict themselves three times a day" (Cortázar 1980: 186).

11 Although first rejected, this famous readymade would eventually find its way to the museum and to many a respected art history book.
} 
life that would never make it to most museums, as well as all that could be added to the world with just a little humor and imagination.

Elusive as few others, Around the Day in Eighty Worlds, and the 1969 book that is routinely considered to be its homologue and sequence, Último round (Last Round), have been referred to in many ways and described with at best partial critical grammars. ${ }^{12}$ Peruvianborn writer Mario Vargas Lłosa, in an essay latter to be used as the preface to Cortázar's Complete Stories, for instance, called these books "miscellanies" (Vargas Lłosa 1997: 32), a term that suggests at best a random gathering of texts; and critic Ilan Stavans - who no doubt had in mind Vargas Lłosa's appraisal of Cortázar's literary legacy — dismissed them, with all the moral implications of the phrase, as "the art of literary promiscuity" (Stavans 1996: 306). ${ }^{13}$ A more sympathetic critic, Monique J. Lemaitre, who identified in these two books many a practical example of the theories exposed by Jacques Derrida, referred to them as "unwritten novels." 14 Around the Day, however, is not an "unwritten novel"; to call it so presumes that it is a text that fell short of a desired standard, that Cortázar abstained from turning the text into a novel and, consequently, that a written novel is the measure of what a text could or should be - that a written novel is an accomplished novel. Another critic, Ana María Hernández de López, more fitly called them "kaleidoscopic books" (Hernández 1987: 194), a term that captures the playful sense of shifting coalescence of heterogeneous elements akin to the organizing principles of culture.

We have some idea of how Cortázar himself liked to think of these books. I mentioned above that some of the blurbs refer to them as col-

\footnotetext{
12 Although Around the Day and Last Round are similar and sequential in many ways (there are, for example, hidden references in the latter to the former), they are dissimilar in other ways that lie outside the scope of this study. Therefore, and as far as possible, I have avoided clumping them together here, although in a certain sense they do belong in the same aesthetic and ideological category. I hope that this study will motivate further research on the links and differences between Cortázar's two almanacs.

13 One of the main arguments of Vargas Lłosa's article is that, in the context of Cortázar's life, promiscuity, along with social concern and political commitment, signaled a turn for the worse.

14 Lemaitre quotes from Stephen Kock's "Flights of Polymath's Fancy": "The $20^{\text {th }}$ Century" writes Kock "has witnessed the emergence of a potent - and I think possibly even new - literary form, which we might dub, informally, the unwritten novel. The unwritten novel is a book, however polished that seems a compilation of fragments. A typical example looks like a salad of autobiography, notebook ecstasies, diaristic confessions, prose poems, epigrams, meditations, shafts of critical discourse. Yet these scattered works are not mere pastiches. They do have unity; but theirs is the coherence of a unifying refusal, an energized denial" (Lemaitre 1988: 186).
} 
lages, a term close to the cinematic montage and one that captures the idea of a seemingly random yet nonetheless calculated gathering of semantically distant and disparate parts. In interviews, Cortázar liked to refer to them as "almanacs", 15 a word derived from the Arabic that implies organization and system: each entry corresponding to a day, week, or month of the year. It is a rather ironic term because in most of the almanacs of the Hispanic world each saint is placed in its proper pigeonhole where it quietly stays until its next turn the year after which is precisely the opposite of what Cortázar does in these books. Somewhere between these two terms, between the apparently casual yet nonetheless calculated juxtaposition of distant signifying worlds suggested by the notion of collage, and the ironic use of the word almanac to comment, with humor, on the accepted order of cultural entries, Cortázar sets forth a sui generis conception of the book.

Sui generis, because in contrast to most novels, essays, and stories, Around the Day does not follow a preconceived plan nor does it strive to achieve a compositional finality. ${ }^{16}$ Around the Day is not meant to be "definitive". I mentioned that in subsequent editions, Cortázar feels free to alter both the graphic dispositio and the content of the first edition. Indeed, Cortázar's first almanac comes close to his aspired aesthetic standard of the jazz take: the book is conceived as a kaleidoscopic series of pieces that are free to shift with each reading and to offer themselves at once as what they are and as what they can be as they interplay with other elements of the text. One of the most ostensible examples of this is "La hoguera donde arde una" ("The Fire That Burns A"). It is a "halfbaked" poem composed of 51 "incomplete" lines, each of which is an instigation for the reader to complete it. Here are a few examples:

To bite in the act of love is not strange when you have

I had moaned, yes, and at some point I was able to

We didn't speak about it after, he seemed proud of

(Cortázar 1980: 83) ${ }^{17}$

\footnotetext{
15 Cf. Cortázar and Prego, 185.

16 I suspect Cortázar would not have wished his work to be encapsulated by this assertion. He would have argued, for instance, that his novel Rayuela (Hopscotch) was "not in any way a book of a writer who plans a novel, not even vaguely" (Prego, 108); but then again, we should keep in mind that he also claimed that his stories - some of which are among the most highly structured stories in Latin American literature - unfastened themselves like monkeys from trees or unexpectedly fell on his head like coconuts.

17 There is a similar poem in Ultimo round.
} 
This is an open-ended and participatory conception of literature that models an often-overlooked aspect of culture. Culture, too, is conformed not of final discourses but rather of a series of signifying proposals that much like jazz takes either prolong or renew, or both prolong and renew, existing cultural codes. The pieces in Around the Day come together in a communal space that is open to the polyphonic voices of culture, a crossroads of mobile semiotic possibilities that ends up drawing a complex picture that is both uncertain and desirable, uncertain because at any given point it is partial and in flux, and desirable because at any given point it is an offer and proposal which we may take or leave. Culture, Cortázar reminds us, is not only the vehicle in which we ride but also the one we drive.

With the steering wheel in our hands, we may choose to repeat old trodden paths, but then the book does not allow us to forget the consequences of individual actions that have led to the ill fated history of the twentieth century and to so many posthumous lives of acquiescence (there to remind us, for example, are the chronicles and images of the atrocities of Viet Nam and of the abduction, maiming and enslavement, of children in Venezuela). Or, with vertigo, anticipation, and some imagination we may take the wheel in our hands and turn into the lane of Journeys and Surprises as naturally as one may turn the door knob and walk into that Kibbutz of Desire that Horacio Oliveira so longed for in Rayuela (Hopscotch), Cortázar's acclaimed 1963 novel. We may also take flight and visit the island of the cronopios; Around the Day, after all, is also the book where a highly grateful and expectant cronopio travels - by plane of course - to "a country of cronopios" (Cortázar 1967: 203).

The cronopios? They are these half-real, half-imaginary creatures, at once ideal and goofy, joyful and hapless, and probably the most internationally popular characters among the many that Cortázar conceived. Most importantly, they are arguably the single most significant cultural contribution of the many he made and one by which Cortázar would have liked to be remembered. In what follows I would like to make avail of these slippery critters to advance in a rather Cortazarian fashion the thesis that Around the Day is a book that, like one of those partial beings in the permeable aquarium that has paused in the frontier that separates what is from what is not and what could be, has remained at the outskirts of culture, that this is a book where the most welcome and unheard of could be born. 
Around the Day, for all practical purposes, is where the first cronopio was born - anachronistically, of course, as any self-respecting cronopio would care to be born. Which is to say that this is the book that, quite some years later, would give popular diffusion to the text where the first cronopio was in fact born. And the first cronopio was Satchmo, Louis Armstrong, born as a cronopio in 1952 (incidentally, the year in which Cortázar arrived in Paris for a long and fruitful exile), properly born as a cronopio in a text titled "Louis enormísimo cronopio" ("Louis the Hugest of Cronopios") first published in Buenos Aires literaria, a journal of limited diffusion. This is the text reprinted in the pages of Around the Day beside a photographic reproduction of old Satchmo sharing with us the enormous smile of the incessantly born anew. Before the republication of this text in Around the Day, many readers in the Spanish speaking world had not only already heard of the cronopios but had incorporated them into their daily vocabulary; few, however, knew that there was a first cronopio and that this first cronopio was a being as human as human beings can get.

The cronopios, those elusive and likeable beings, had made their multitudinous entrance and became cultural icons in 1962 after the publication of what Vargas Lłosa, likely thinking of the Spanish adjective travieso, called "the most mischievous" of Cortázar's books: Historias de Cronopios y de Famas, ${ }^{18}$ translated into English in 1969 as Cronopios and Famas by Cortázar's friend, the poet Paul Blackburn. ${ }^{19}$ The cronopios did not come alone; Cronopios and Famas introduced two other character types, the famas and the esperanzas, the complements and counterparts of the cronopios. Cortázar was and remains a well-read author, ${ }^{20}$ Cronopios and Famas has been reprinted in Spanish over thirty times, and Around the Day does not trail far behind. Many readers today, as they did in the sixties and seventies when they first encountered these indelible beings, will refer to someone they know, or even someone they see walking in the street as a

\footnotetext{
18 Cortázar wrote the text after attending a Louis Armstrong concert in the Champs Elysées on November 9, 1952. In the tradition of Macedonio Fernández, Cortázar distributed among his friends an early mimeographed version of his Cronopios and Famas before it was published as a book.

19 In one of the first pieces of Last Round ("Uno de tantos días en Saignon") Blackburn arrives to Cortázar's place in Saignon "with the tremendous decision" to stay ten days so that he may be able finish with Cortázar's help the Anglo-American translation of Cronopios and Famas.

20 This is true specially among European and Latin American readers but also in the US and many other cultures of the world into whose languages Cortázar's work has also been translated.
} 
cronopio, or a fama, or a esperanza, as the case may be. But who are these elusive critters that have managed to become part of the repertoire of Latin American culture?

I will try to describe them here in the double context of the dialectics between the center and periphery of culture and of the renewal and persistence of cultural repertoires. Let us begin with the famas. Their name is derived from the Spanish word for fame. The famas are subjected to the center of culture; they feel at home in the agreed and prevailing repertoires and stick to the most structured languages and the correct practices of culture. They are also the easiest to define characters of the triad: their image of the world is made according to the norms of the "correct", the rest does not exist. They are the diligent bearers of the sanctioned semiosis of culture.

The esperanzas are the indecisive beings; they mediate between the cronopios and the famas. Their name in Spanish indicates that they are hopes, perhaps a hope to achieve the status of a cronopio, but not quite. In the country of the cronopios, "the cronopios have pulled out the color chalks that they always take with them and have drawn and enormous, THAT'S IT, in the walls of the famas, and with smaller and more compassionate writing, MAKE UP YOUR MIND, in the walls of the esperanzas" (Cortázar 1980: 173). They are the undetermined and for the most part inconsequential beings of the triad.

The cronopios, on the other hand, are indeterminate but plausible and even necessary beings that effortlessly slip away from every pigeonhole that society and language tends to put them in. They are by nature peripheral beings; there is something childlike about them, an often impractical but delightful eccentricity that goes against the grain of our accepted ways of knowing and perceiving - they are the tender caricatures of the humans we could be if someone rescued us from all the seriousness and solemnity that characterizes a great deal of our waking lives. Like Louis Armstrong - and I am grateful for the luck to write about him in the year of his centenary - the cronopios corrode, without wishing, or even knowing it, the established norms of culture; but like Louis, they too frequently end up being tenderly accepted (although the famas will do so with a delicate frown). They are the bearers of things that they ignore; their main contribution, for instance, has been, as I said, to expand the repertoire of Latin American culture, a feat which the cronopios would never think of, much less take credit for. I said that many of us today can spot a cronopio in our mist; many also secretly aspire to see the world like one. This is a 
playful aspiration that rejects both the rigor mortis of intellectual stiffness and the snobbish hope to belong to the top echelons of culture, to be part of the fashionable elite or the noble intelligentsia.

In Cronopios and Famas, Cortázar made it simultaneously intuitively easy and rationally difficult to understand the cronopios (it seems that much more is said there about the famas and the esperanzas). It is in one of the last pieces of Around the Day, that Cortázar draws a fuller picture of these critters. In "Viaje a un país de cronopios" ("Journey to a Country of Cronopios") we have the exceptional fortune to witness what could happen in a planefull of cronopios. A cronopio, in my place, would now proceed to translate at least two full pages of that text and as a consequence would inevitably be flooded with letters from publishers notifying him in enigmatic lingoes of copyright infringements. I will limit myself to paraphrase. As soon as the cronopios are seated in the plane that is to take them to the desired island of the cronopios, they are notified by the company that they have to go back down to the airport because there is a lay over of more than two hours. It is to be expected that the cronopios will run into a web of obstacles when they travel (cf. "Viajes" in Historias (Cortázar 1989: 123), and it is also "a well-known fact," and now I do allow myself to translate and quote at length,

that the cronopios don't worry about such things, because immediately they think that the company is going to serve them big-tall glasses of juices of different colors in the airport's bar, not to say that they will be able to keep on buying postcards and sending them to other cronopios, and not only does this happen but on top of it the company has them served a succulent dinner at eleven p.m. and the cronopios can thus accomplish one of the dreams of their life, which is to eat with one hand and write postcards with the other (Cortázar 1980: 177).

I will say no more about the cronopios, except to mention that they are not afraid of tigers (especially of those that threaten our enjoyment of life), and that they always surf, with a sense of wonder and great enthusiasm, outside the accepted norms of culture.

What is interesting in the context of our discussion is that much like the cronopios, Around the Day, the book that told us about their progenitor and their country, has also managed to surf for years somewhere between the center and the periphery of culture. Compared with Cronopios and Famas, a book commonly acknowledged to be at the heart of the canon of Cortázar's opus, or to Hopscotch, a book widely recognized as one of the two "classic" novels of $20^{\text {th }}$ Century 
Latin American literature (the other is A Hundred Years of Solitude by Colombian writer Gabriel García Márquez), critics do not quite know what to do with Around the Day. The rich and variegated corpus of Cortázar's stories and even 62 modelo para armar (1968) (62 Modeling Kit), which is an extremely difficult to categorize narrative, have settled in considerably firmer critical ground. Around the Day in Eighty Worlds, however, remains a satellite whose orbit, both in the context of Cortázar's work and in that of Latin American literature and culture, critics have largely been unable to adequately chart.

How can this phenomenon be explained? I think one way to explain the elusiveness of this book is by observing its affinity with the operations of cultural intersemiosis. It is a rather paradoxical affinity. Around the Day models the operations of culture as seen from the outside, while at the same time it assiduously goes against the grain of accepted norms of culture as seen from the inside. Cortázar's first almanac situates itself at a metasystemic perspective that is both critical and creative. Much like culture, the book's rhetorical dispositio follows a principle whereby an array of semiotic spheres gather together around an aleatory riff of surprising and meaningful encounters. And much like those "hot spots" where cultural repertoires clash, interact, and find renewal, each reshuffling of the book's takes generates extraordinary codes that heighten the level of information of the system. Around the Day in Eight Worlds is a rare book that manages to simultaneously take a part in, reflect, and recreate the game relationships of cultural interplay.

One final analogy: like the cronopios, those slippery beings who know so much about the power of the merry and the unexpected and so very little about the seriousness of our endeavors, Around the Day is an exceptional kaleidoscopic book that I suspect will remain for long at play at the outskirts of culture.

\section{References}

Barthes, Roland 1974. La Antigua Retórica: Ayudamemoria. Trans. Beatriz Dorriots. Buenos Aires: Tiempo Contemporáneo.

Cortázar, Julio 1962. Historias de Cronopios y de Famas. Buenos Aires: Ediciones Minotauro.

- 1963. Rayuela. Buenos Aires: Sudamericana.

- 1967. La Vuelta al Día en Ochenta Mundos, First edition. Mexico and Buenos Aires, Siglo XXI Editores. 
- 1968. 62/Modelo para Armar. Buenos Aires: Sudamericana.

- 1969. Ultimo Round. Mexico, Siglo XXI (Printed and made in Italy).

- 1980. La Vuelta al Día en Ochenta Mundos. Madrid, Siglo XXI.

- 1986. Ultimo Round. Mexico, Siglo XXI.

- 1989. Historias de Cronopios y de Famas. Buenos Aires : Sudamericana.

Cortázar, Julio and Ana María Barrenechea 1983. Cuaderno de Bitácora de Rayuela. (Preliminary study by Ana María Barrenechea). Buenos Aires: Sudamericana.

Cortázar, Julio and Omar Prego 1985. La Fascinación de Las Palabras: Conversaciones con Julio Cortázar. Barcelona: Muchnik Editores.

Esquivel, Laura 1989. Como agua para chocolate. New York, Anchor Books.

Even-Zohar, Itamar 1999. The making of repertoire, survival and success under heterogeneity. (Paper presented to the $5^{\text {th }}$ IASS International Congress, Dresden, 6-11 October 1999.) Available on-line: http://www.tau.ac.il/ itamarez/papers/rep-success.htm

Hernández de López, Ana María 1987. Los ochenta mundos de la vuelta al día. In: Burgos, Fernando (ed.), Los ochenta mundos de Cortázar: Ensayos. Madrid: EDI-6, 191-98.

Lemaitre, Monique J. 1988-1989. Julio Cortázar y la novela no escrita. Explicación de textos literarios 17 (1-2): 186-203.

Lezama Lima, José 1972. Cortázar y el comienzo de la otra novela. In: Giacomán Helmy (ed.), Homenaje a Julio Cortázar. New York: Anaya, 1329.

Sanjinés, José 1993. (TANGO): a metaphor of collaborative art. Point of Contact 3 (3): 91-103.

Stavans, Ilan 1996. Justice to Julio Cortázar. Southwest Review 81 (2): $287-$ 310.

Vargas Lłosa, Mario 1997. The trumpet of Deya. The Review of Contemporay Fiction 17 (1): 25-34.

Varricchio, Andrea 1988. El mundo visual en La vuelta al día en ochenta mundos. Discurso literario 6 (1): 63-70.

Uspenski, B. A. et. al. 1998. Theses on the semiotic study of cultures. Tartu Semiotics Library 1: 33-60.

\section{Книга на периферии культуры: первый альманах Кортасара}

Понятие интерсемиозиса предполагает игровые соотноиения между многими взаимодействуюшими знаковыми сферами культуры, но сам термин вполне может применяться и в изучении некоторых особых художественных текстов. Данное исследование имеет целью показать на примере одного из них, "Вокруг дня в восьмидесяти 
мирах" Хулио Кортасара, как своеобразное взаимодействие семантических сфер текста одновременно моделирует и обновляет сложные культурные процессы производства значений. Эта часто переиздаваемая и трудноопределимая книга, долгое время остававшаяся на периферии латиноамериканской культуры, - идеальный пример для изучения динамической связи культурного центра и периферии, а также роли писателя в творческом обновлении репертуаров культуры. Перекидывая мост через промежуток, отделяюший семиотику культуры от семиотики художественного текста, данное исследование по своему духу является попыткой приблизиться к критическому творчеству выдающегося покойного теоретика Юрия Лотмана.

\section{Raamatud kultuuri perifeerias: esimene Cortázari almanahh}

Intersemioosise mõiste eeldab mängulisi seoseid paljude teineteist mõjutavate märgiliste kultuurisfääride vahel, kuid terminit ennast võib kasutada ka mõningate eripäraste kunstitekstide uurimisel. Antud uurimuse eesmärgiks on näidata ühe taolise teksti, Julio Cortázari "Ümber päeva kaheksakümnes maailmas" näitel kuidas teksti semantiliste sfääride omapärane koosmõju üheaegselt nii modelleerib kui ka uuendab tähendusloome keerulisi kultuurilisi protsesse. See mitmes trükis ilmunud raskestilahterdatav raamat jäi tükiks ajaks ladinaameerika kultuuri perifeeriasse ja on ideaalseks näiteks kultuurilise keskme ja perifeeria dünaamilise seose uurimisel, aga samuti kirjaniku rolli määratlemisel kultuuri repertuaaride loomingulises uuendamises. Olles sillaks kultuurisemiootika ja taideteksti semiootika vahel, püüab antud uurimus läheneda silmapaistva teoreetiku Juri Lotmani kriitiliste tööde vaimule. 